\title{
A Predictable Future?
}

How Self-Deception Replaced Profound Analysis

Sergei A. Karaganov

Most foreign and Russian international relations experts, regardless of their political leaning, seem to agree that the world has become unpredictable, uncertainty is increasing, this process cannot be influenced, and it would be better to step aside and do nothing.

This conclusion is particularly dangerous for us Russians. Unfortunately, we are quite good at falling into a trance after making major breakthroughs and at losing peace after winning wars. But I will say that the future is quite predictable, and it can and must be influenced, if, of course, key players know what they want, have the energy and intellect, and build their policies on a more or less rational and long-term basis.

There has always been an element of uncertainty. And there is no more of it now, and probably even less, than before. The information revolution has given people more opportunities for influencing politics, and this is what worries the elites who have become used to deciding what people need. This partially explains their complaints about supposedly growing uncertainty. In reality, broader participation of society in politics makes it more predictable because the interests of large masses are easier to calculate than intrigues devised by the establishment.

Sergei A. Karaganov, Doctor of History, is Dean of the Faculty of World Economy and International Affairs of the National Research University-Higher School of Economics (NRUHSE), and Honorary Chairman of the Council on Foreign and Defense Policy, Russia. 


\section{IDEOLOGICAL AND POLITICAL MISTAKES}

The main reason for all the talk about unpredictability is the unwillingness of Western elites, who used to dominate the intellectual sphere, and those who followed in their footsteps to see the unpleasant around them. The intellectual and political class in Europe has come to believe in the inevitable global victory of the European model, which can be imposed upon others due to the potential (political, military, economic, ideological, and informationall accumulated by the West. In relatively poor non-Western countries, such as Russia, the study of European integration was financed mainly by Europeans, with the predictable result. Only the United States showed "Euroscepticism" as it could afford its own intellectual vision and did not want its competitor, albeit allied, to become stronger.

The current state of the European Union could be foreseen as far back as the early 1990s, when the majority of European states got access to cheap labor and former socialist countries' markets, and decided against overdue economic and social reforms. This mistake was exacerbated immensely when the European Union, swept by euphoria from what seemed to be its ultimate victory, tried to develop "a common foreign and defense policy." The search for the lowest common denominator diminished the influence of leading European powers dramatically. The EU started a thoughtless enlargement and introduced the euro without building a common economic governance system.

Europeans also rejected integration with Russia which had "hard power," resources, and history-proven ability to rebuild itself. On the contrary, they opted for a neo-Weimar policy. The Russian elite, tired of "real socialism" and its hardships, sought to become closer, if not integrate, with the EU, on decent conditions, of course. Had this happened, the current weakening of the West would not be so painful and it would have retained its military supremacy-the basis of its economic, political, and ideological dominance-for a long time.

When the EU ignored Russia's wish to become closer and NATO started expanding, I got frightened. In fact, Moscow's 
proposal was so generous that its rejection looked like a desire to finish off the former adversary, to deliver a coup de grace. After that the only question was when a clash would occur and on what terms, and whether we would have enough time to prepare for it. A new confrontation became inevitable after the United States' secession from the ABM Treaty, which could only be interpreted as its desire to regain strategic superiority. This looked particularly dangerous amid the acts of aggression committed against Yugoslavia and Libya. It is remarkable that most specialists both in Russia and abroad were surprised by events in Crimea and Ukraine in 2014 or saw them as a sign of Russia's "unpredictability," even though they were quite logical and could actually have gone worse. The refusal of a major part of the Russian elite to face reality did not affect the logic of history. Another part of the Russian ruling class accepted it and acted accordingly, preparing inconspicuously for a harsh confrontation. A new generation of strategic and sub-strategic weapons was created, financial reserves were built, and the administrative system was fine-tuned. But a large part of the Russian establishment, especially its economic segment, did not want to believe in the inevitable. Otherwise, they would not have launched a project to build a new civil aircraft, MC-21, so heavily dependent on American components; they would have been quicker in creating independent payment systems in order to neutralize and deter sanctions; the Russian rich would have stopped moving their assets to the West; and they would not have daydreamt about an end of sanctions as they did until recently.

The sanctions were easily expected not only because of the confrontation, unavoidable after the retreat in the 1990s, but also because of partial deglobalization, which led to the politicization of economic relations. This process was caused by a series of objective factors, above all final loss by the West of its military superiority and, consequently, almost five-hundredyears-long political and economic dominance. Countries and peoples, hitherto suppressed, got an opportunity to use their competitive advantages. In this situation, "the liberal economic order" stopped benefitting those who had created it. And the United States started backtracking on it long before Trump. 
Multiple sanctions imposed by Europeans and Americans alike even before the outbreak of protectionism in the U.S. were justified quite explicitly by the impossibility to use military force.

The result of all those steep turns was quite predictable. The European Union entered a multidimensional, and possibly even fatal, crisis, and its geostrategic influence began shrinking in the increasingly competitive world. Nor was it completely unexpected that a person like Donald Trump would eventually come to power. America got involved in several wars and lost them politically, having wasted trillions of dollars so recklessly. The U.S. infrastructure is in a sorry state for such a rich country. China has made a major leap forward, pushing Americans aside not only in the economic but also political markets. When Barack Obama took office, he had already had a mandate from a part of the ruling class to reduce the country's external obligations and focus on internal development. But just like President Jimmy Carter, he was unable (or was not allowed) to do that. At the end of the 1970s, the elite nominated Ronald Reagan, who prioritized economic revival and restoration of military supremacy. The difference between Trump and Reagan is that a major part of the ruling establishment in the 1990s-2000s became so convinced of their infallibility and the power of liberal dogmas that they completely forgot about national interests, and, having encountered an inevitable reaction to expansion, split up. Correction is proceeding with great difficulty and against the will of the elite. But Trump came as a surprise only to them and those who had become used to feeding off their ideological products.

Because of its delusions amplified by the desire to impose its views, the West failed to notice China's revival. Its policy vis-à-vis China was based on the unwillingness to accept the obvious: China's thousands-year-old culture and historical tradition. Had China with its diverse population of more than 1.3 billion become truly democratic, a global catastrophe would have become unavoidable. It was believed that once it accepted capitalism, it would without a doubt become more democratic, pro-Western, and, therefore, less able to manage itself and its own resources. When it had transpired by the beginning of 
the 2000s that things were not going this way, Western pundits started talking about China's inevitable collapse, claiming that capitalism could not develop without democracy.

However, capitalism was developing regardless of democracy but on the basis of the legal system inherited from feudalism, which protected private ownership, and political models, which now would be considered radically authoritarian. Moreover, capitalism, whose main driving force is inequality, is at variance with democracy, that is, rule of majority. "Populism," which Russia has been accused of supporting, is the absolutely logical result of a new outbreak of inequality and growing immigration which has gone out of control. Few remember that it was started in the 1970s by the European bourgeoisie in order to reduce rising labor costs and the influence of trade unions. Today they are picking the fruits of their decisions.

\section{INTELLECTUAL DELUSIONS}

One of the main reasons for the current panic over unpredictability is the collapse of the intellectual foundation upon which global and Russian elites made their calculations. Created by the West in the past forty years, it became prevalent after its temporary "victory" in the Cold War.

Everybody rushed to study, teach and spread the doctrines and ideas of the Western academic community as an indisputable truth. Besides, the West was freer and richer, and for that reason alone more attractive, and on top of it all its media dominated the intellectual sphere. However, most of those theories, concepts and schools have serious flaws.

First of all, their adepts, willingly or unwillingly, reflect the interests of their countries or their ruling elites. Those who follow them in other countries play by someone else's rules and on someone else's turf. Sometimes, they ignore the interests of their own countries purposefully for comprador reasons or through folly, ignorance or desire to please their colleagues from the "advanced world." In Russia in the 1990s there were many intellectual and political leaders who proclaimed their country's interests identical to those of the West, and all decisions coming 
from the West were considered unquestionably correct. We can still hear the echo of those decisions.

Secondly, all those concepts, as a rule, were written for the bygone period of bipolar confrontation or "liberal world order" in 1991-2007, an era of U.S. domination. Even if they somehow reflected the real picture of the world before, they have become outdated now.

Thirdly, over the past fifty years the Western economicpolitical and social thought has split up into a number of narrow schools. But a selective view does not make it possible to see the whole picture and, therefore, foretell the evolution of such complex systems as societies or international relations.

Finally, fourthly, many theories were simply erroneous. Belief in the "end of history" and indisputable correctness of liberal-democratic theories and practices played a nasty trick. These were followed by an era of political correctness, while liberal-democratic views transformed to some kind of totalitarian ideology las Alexander Lukin has observed so shrewdly).

None of the above means that all of the Western theories are wrong. The school of political realism, fiercely rejected by the intellectual majority in the U.S. and Europe, is largely correct. Samuel Huntington's concept of the "clash of civilizations" proved to be rather prophetic. The balance of power theory also appears to be quite adequate, even though it is rejected, for different reasons, by both liberals and China. The latter is used to dominating in line with its "Middle Kingdom" tradition rather than to balancing, but as China gains experience, it, too, is beginning to play by the rules laid out by the balance of power theory.

Let me give you a couple more examples of mass intellectual delusions. It has become almost a standard practice to believe that Western democracy is the ultimate form of human development. Communists thought for almost a century it was communism. But democracy always died when international competition tightened or internal turmoil broke out. Hellenic republics became despotic, the Roman Republic turned into an empire, medieval Italian republics became monarchies, the 
Novgorod Republic fell, the Republic of Venice surrendered to Napoleon, and almost entire democratic Europe surrendered to Hitler. If it had not been for the selfless struggle of the Soviet people led by a totalitarian regime, there would be no democracy in Europe as we know it.

Modern Western democracy is only one of the ways, albeit more comfortable for the majority of people, to govern societies. The future promises a pluralism of models. And yet faculty members in most universities stick to the politically correct narrative and keep on convincing themselves and their students that the victory of democracy is inevitable despite the fact that authoritarian tendencies are growing even in Western societies.

The myth about peace-loving democracies and their commitment to international law continues to prevail among intellectuals. True, it is harder for democracies to fight long wars. But how can one speak about "a democratic peace" after NATO's 80-day bombing of what remained of Yugoslavia, a rather democratic country although partly torn by civil war? It was started with the help of EU democracies which unlawfully recognized the independence of Croatia and Slovenia in 1991. This was followed by aggression against Iraq and Libya committed by the majority of official democracies.

Spasmodic efforts to find and create an enemy show that its existence is crucial for Western political systems. All "populists" and opponents of failed elites are proclaimed Putin's agents. The situation in the United States is even more thrilling. The losers tried to explain their failure by concocting tales about Russia's alleged meddling in American elections. They have also revived the absurd myth about the Russian military threat, even though Russia's military spending is less than one-twentieth of the combined NATO's defense budget, and its armed forces are only a small fraction of the former Soviet ones. When the anti-Russian campaign started to run out of steam by 2019, they stepped up the demonization of China, accusing it of all possible sins, the main of which is that it is allegedly trying to "undermine" democracy. The Chinese are astounded and cannot understand what it going on. 
I recall with a smile how more than four decades ago I was studying the works of Joseph Nye, Robert Gilpin, and Robert Keohane, the pioneers of the modern theory of globalization, who drew pictures of a new bright world glued by interdependence, with nation states replaced with supranational institutions, transnational corporations, and NGOs. I believed in this for a while myself. However, I am surprised to see that these theories are still taught, even in Russia. But where is a global government? World politics is becoming more national, and international institutions are breaking up. Transnational corporations obediently follow governments' orders. Ninety nine percent of global NGOs are controlled by states or groups of elites.

The theory of "soft power" put forward by Joseph Nye, an excellent intellectual and ardent proponent of his country's interests, has proved inept. And yet, if this theory is stripped of its pro-Western bias and called the old name-ideological influence-it would turn out that Soviet communism possessed colossal "soft power" in the 1920s-1930s despite poverty and repressions. Its calls for universal justice, equality and national liberation were followed by hundreds of millions around the world. Modern Russia, too, has "soft power" even though it is not very rich and not very free. Russia's ideological messageprotection of sovereignty, national dignity, cultural identity, and traditional values -is close to most peoples. This is one of the reasons for the nasty anti-Russian information campaign that has gone beyond the bounds of decency.

The rejection of theories of imperialism is also strikingly ridiculous. In fact, the United States, which denies them most fiercely, is a classic example of an empire, with no formal colonies but with 800 military bases around the world and the determination to impose its ideology, foreign policy, and its choice of foreign economic ties. The European Union is an even more evident form of empire, albeit without an emperor. Should the rest of the world follow in the footsteps of this hypocrisy? Or do empires exist and will exist and the future belongs to them?

There are countless examples. Most of the existing theories are only partly viable. They are useful as an instrument of 
analysis, but only if one understands that their practical applicability is limited.

\section{NOW ABOUT THE FUTURE}

The only thing that can change everything is a big war. It will make the course of history completely unpredictable or bring it to an end altogether. I have written many times that its probability now is much higher than any time since the middle of the 1960s.

But it can be prevented by a smart policy, multilateral mutual deterrence and active struggle for peace. Other macro tendencies are rather obvious and predictable. I will name the most important of them.

- The center of the world economy and politics will keep shifting into Asia. China, even if its slowdown is inevitable, will catch up with the U.S. in terms of comprehensive power in the foreseeable future. It is probably already catching up or even surpassing the U.S. in some of the technological and strategic areas such as artificial intelligence. Cultural and moral influence will drift towards Asia and Eurasia as well, following military, economic and political power. This will open up interesting prospects for Russia and North Eurasia.

- Owing to the "Trump revolution," which has spurred the economy, the U.S. will most likely retain its status as power number one/two, but less so as a super global player, and will partly retreat to the Western Hemisphere.

- The de facto Cold War, which the West is starting against China in a bid to organize itself against the "enemy" and contain the growth of the Chinese power, will remain one of the major trends in international relations in the years to come. The division of American elites may be partly mended in four or six years when they retake control of social media and the political system of the country as a whole. This may moderate their search for an enemy in Russia as China seems to be viewed more and more often as such instead. The interests of the "starving" American military-industrial complex related to strategic weapons will be met to some 
degree. What is important is that we have made it clear to the Americans just in time that they will not achieve superiority by "bleeding us white" with a new arms race and that there will be no second edition of Reagan's "victory." In this case we can expect some normalization. But the other causes of confrontation will remain in place. For Washington, which has allowed Moscow and Beijing to build a semiallied relationship, it is important either to defeat Russia or neutralize it in order to weaken China or tear it away from Moscow.

- Europe seems to have missed the chance to reverse the degradation of its project and international positions. Nationalistic and authoritarian tendencies will increase. A downward and regressive drift is likely to continue until a new balance is found at the level of the late 1980s-early1990s. However, European powers will never regain their previous independent positions in world politics because of the failed common defense and foreign policy experiment and internal European problems. External forces will step up their fight for the withering but still splendid and rich subcontinent. This struggle may pose a serious geopolitical challenge to Russia and the world. Europeans did not want to bear the cost of their security and defense, and now they have to pay for that with political loyalty and economic concessions. The comprador class, which associates its political and economic interests with the Americans, remains quite strong. The U.S. has created a broad clientele in Europe. The European Union's expansion strengthened its pro-American forces-ideological Russophobes or just deeply corrupt and weak governments, whose leaders are "on the hook." But the campaign to make "an enemy" out of Russia is losing steam. There are more and more objective conditions for improving relations with Europe. However, these are likely to be relationships with individual countries of the sagging European Union.

- In geopolitical and geo-economic terms, the world will become increasingly pluralistic, with two centers of gravityAmerica and Greater Eurasia. The former will encompass 
members of the reformatted NAFTA, some Latin American countries, Great Britain, and part of European states. The future of the latter and its contours will depend primarily on Beijing's ability to overcome the historical inertia of the "Middle Kingdom" approach designed to create vassal states around it. This strategy does not fit into China's new global role, and regional great powers will sooner or later rally against China, with the U.S. possibly joining them at some point. Eurasia, which has inherited a strong conflict potential from the past, will turn into a macro region of fierce competition. If China decides to become the first among equals, actively starts building cooperation institutions, primarily the Shanghai Cooperation Organization, and consciously immerses itself into the network of ties and balances, the partnership of Greater Eurasia will become a reality, no matter what it is called: a giant continent of global cooperation, development, and interaction of great cultures. The situation will take some five to seven years to work out.

- The world as a whole will become freer. However, the incredibly rapid shift in the global balance of power, regionalization of world politics, the new strengthening of the role of nation states, rekindling of conflicts which were kept under control in the past by the then hegemons, the Soviet Union and the United States, and the emergence of new weapons will impact international strategic stability and create a relatively high probability of big war. The military factor will remain and may even become more significant both in terms of security and as an instrument of influence.

- Intellectual degradation of mankind is likely to continue, affecting among others, or probably even more than others, the ruling classes in many countries due to the information and digital revolution. This tendency first appeared some twenty years ago along with the "television generation" which is inclined to react automatically to the latest news and images. It will become even more pronounced when the "iPhone generation" grows up as it can hardly distinguish reality from virtual reality and is increasingly unable to think independently, critically, and in a historical perspective. 
Modern democracies where people elect their likes are an anti-meritocratic mechanism. It is quite probable that the main criterion for selecting leaders in countries where selecting can still be possible will be invulnerability of candidates or their groups against the Internet.

- The role of mineral resources will keep decreasing. However, the importance of renewable resources, such as food, marine bioresources, clean fresh water and air, and forests will increase in world politics and eventually in geopolitics (this tendency was detected and substantiated by Igor Makarov of the National Research University-Higher School of Economics). Therefore, the value of territories where these resources can be produced will grow again.

- The de facto disappearance of communist and the decline of liberal ideologies are creating a vacuum. Competition is unfolding for filling it with nationalism in its state, ethnic, or even quasi-religious form. There is demand for a new ideology for a new world.

- The tendency towards partial deglobalization will continue due to both growing geopolitical rivalry and localization of production made possible by the digital revolution. Politicization of international economic relations and the use of economic leverage will continue, too. One should not expect a return to the relatively liberal economic world order until a new global military-power framework is created, and the conventional West adapts to the new balance of power.

- The consequences of climate change, regardless of its causes, are well known.

- Growing inequality or a sense of it is a major internal and international challenge to be faced by the majority of states (Russia among the first). This inequality will continue to increase, creating demand for a new ideology of development.

- Rapid changes in the global balance of power will cause further degradation of most institutions created by the previous world systems-bipolar and unipolar. These institutions are either obsolete or harmful, and keeping them running by participating in them becomes increasingly senseless or counterproductive. 


\section{WHAT'S TO BE DONE?}

The old world system is falling apart and a new one is emerging. Despite relatively modest resources, especially economic ones, which need to be multiplied in the first place, Russia is third among the four or five countries which will play a key role in building this system. There are simple principles that must be learned for effective participation in this work.

- One must not fear the inevitable created by macro tendencies. The future always offers different opportunities for adaptation and active influencing.

- There are no rules any more. We must thank Trump for making us finally understand this, for he says and does what his predecessors hypocritically hushed up before. But in this fight without rules, we Russians have a competitive advantage owing to our history, bravery, ideological openmindedness, and readiness to take risks. We only need to stop foolishly following other people's rules and institutions so unceremoniously ignored by our partners. If the world is offered "the law of the jungle," we must act by "the law of the taiga." Those who are trying to stick to the old rules out of habit or desire to get their long-standing partners' smile of approval must understand what they are doing. They have a right of delusion, but the country and its elite do not.

- In a new world, the winners will be those who pay minimal attention to the information environment and pursue a policy based on a realistic assessment of the future. In order to win, one needs to be able to combine intellect with realism and political will.

- Almost all foreign policy concepts inherited from the bipolar and unipolar eras are either obsolete or false. Russia must stop dragging in the wake of the old foreign policy thought which is obviously used more and more selfishly for protecting the waning positions of the West. Russians must develop a new theory and practice of international relations, using without a doubt the previous experience, including the Western one.

- Most of the remaining institutions are either in decline or harmful, the only exception being the UN, its Charter and 
some of its daughter organizations. New institutions are needed, which will not be linked to the disintegrating system of international relations.

- West-centrism in politics and thinking has become archaic and detrimental, but particularly U.S.-centrism which gives additional trump cards to the country that has declared itself our enemy. Spiteful anti-Westernism-the other side of the old Euro- and U.S.-centrism-is absolutely senseless.

- It is necessary to admit the importance of the East and the South and raise public awareness of them and their knowledge, for this is where the main economic and political markets of the future are.

- Let me repeat, we should enhance our competitive advantages: military capabilities, ideological openmindedness, and boldness. No "political correctness" any more-the rules of the old system have been rejected by those who created it.

- Russia must take the leap into a new digital era, but at the same time steadfastly mitigate negative consequences of digitalization, including intellectual degradation of elites.

- Russia should start formulating and promoting its own concept of the future and its role in it. Russia is a guarantor of peace, the creation of a community of independent nations cooperating with each other, and cultural and political diversity. The purpose of its policy is maximum democratization of international relations; in the long run, restoration of the rules and international law which has been trampled upon lately, with the strongest emphasis on a positive agenda.

\section{THE MAIN PURPOSES OF POLICY}

- Creating an area of cooperation, development and security in Greater Eurasia, including integration, jointly with EAEU partners, into a super-continental system of free trade zones.

- Focusing on the development of an EAEU-EFTA-EU-China free trade zone in the medium term. (In the future economic 
conditions such a free trade zone does not look as dangerous as most Russian experts think).

- Maintaining close semi-allied relations with China in the foreseeable future (six or seven years). Their further development will depend on whether our neighbor wants to and can become the first among equals within the framework of Greater Eurasia and immerse itself into the network of balances and cooperation institutions or it will choose to be a leader all by itself.

- Paying special attention to the development of relations with India, which have been falling behind the possibilities and needs of the new world.

- Developing cooperation with European countries within Eurasian formats as much as possible.

- Consolidating the achieved level of the EAEU's development. Improving the implementation of its decisions and securing sufficient public support for its work. Preparing for a new round of its enhancement (and enlargement) in two to three years' time.

- Launching trilateral (with a possible expansion) interaction between Russia, China, and the U.S. is an important strategic goal both in terms of improving world governance and preventing a catastrophic war. This triangle should serve as a prototype for a "Concert of Nations" in the 21 st century. There is no other way to ensure more or less effective governance. This idea has been proposed in Russia before, but, as often happens, it was never pushed forward hard enough. However, conditions are ripening for its implementation.

- And naturally, pursuing an effective policy of economic growth, without which no winning strategy can be possible. 